\title{
Alphalinolenic acid, a potent inhibitor of fatty acid synthase antimycobacterial agent
}

\author{
Mallika Jainu, A Hemaprabha*, S Vinutha, Sarah Rajitha, TS Ranjani \\ From 2nd International Science Symposium on HIV and Infectious Diseases (HIV SCIENCE 2014) \\ Chennai, India. 30 January - 1 February 2014
}

\section{Background}

The mycobacteria become resistant since their slow growth phase increases its ability to adapt and acquire new resistance mechanisms. Presently the first line therapy against TB includes the use of isoniazid and rifampin, which are probably the most effective mycobacterial drugs available today and then there is a very small chance to treat the disease since other newer drugs are seriously limited by gastrointestinal, renal and/or neurological toxicities. Therefore, the search for new ways to treat TB is of primary importance and urgency. Alphalinolenic acid (ALA) is a potent inhibitor of fatty acid synthase (FAS) in a variety of prokaryotic and eukaryotic cells.

\section{Methods}

Using a standardized mycobacterial susceptibility test, we have observed that ALA inhibits the growth of several species of mycobacteria, including tuberculous species such as Mycobacterium tuberculosis (H37Rv and clinical isolates) and Mycobacterium bovis BCG.

\section{Results}

Alpha linolenic acids are toxic to mycobacteria, such as Mycobacterium tuberculosis $\mathrm{H} 37 \mathrm{Rv}$, with minimum inhibitory concentrations (MICs) of 25-50 $\mu \mathrm{g} / \mathrm{mL}$ and Mycobacterium bovis with minimum inhibitory concentration of $6.25-25 \mu \mathrm{g} / \mathrm{mL}$.

\section{Conclusion}

Our data demonstrate that ALA as a prototypical inhibitor, significant antimycobactericidal effects was seen with Mycobacterium tuberculosis and Mycobacterium bovis. A possible antibacterial mechanism was postulated

\footnotetext{
* Correspondence: ahems.8900@gmail.com

Department of Biomedical Engineering, Sri Siva Subramaniya Nadar College of Engineering, Kalavakkam, Chennai -603110, India
}

to proceed via disruption of the bacterial cell membrane resulting in a change in membrane permeability.

Published: 27 May 2014

\section{doi:10.1186/1471-2334-14-S3-E19}

Cite this article as: Jainu et al:: Alphalinolenic acid, a potent inhibitor of fatty acid synthase antimycobacterial agent. BMC Infectious Diseases 2014 14(Suppl 3):E19.
Submit your next manuscript to BioMed Central and take full advantage of:

- Convenient online submission

- Thorough peer review

- No space constraints or color figure charges

- Immediate publication on acceptance

- Inclusion in PubMed, CAS, Scopus and Google Scholar

- Research which is freely available for redistribution

Submit your manuscript at www.biomedcentral.com/submit
() Biomed Central 